\title{
Perspectives on mosquito impoundments in eastern Florida, USA: Reply to Rey et al. (2009)
}

\author{
Karen L. McKee ${ }^{1, *}$, Beth A. Middleton ${ }^{1}$, C. Edward Proffitt ${ }^{2}$, Donna J. Devlin ${ }^{2}$ \\ ${ }^{1}$ U. S. Geological Survey, National Wetlands Research Center, 700 Cajundome Boulevard, Lafayette, Louisiana 70506, USA \\ ${ }^{2}$ Department of Biological Sciences, Florida Atlantic University, c/o Harbor Branch Oceanographic Institution, \\ 5775 Old Dixie Highway, Ft. Pierce, Florida 34946, USA
}

\begin{abstract}
A Comment by Rey et al. (2009; Mar Ecol Prog Ser 389:295-300) documents disagreements with Middleton et al. (2008; Mar Ecol Prog Ser 371:117-129), which explored the characteristics of mangrove swamps managed for mosquito control in the Indian River Lagoon, Florida, USA. Rey et al. (2009) provide no data or evidence that invalidate the conclusions in Middleton et al. (2008). Most of the 'factual errors' and 'methodological problems' raised by Rey et al. (2009) are either unfounded or minor points, or reflect differences of opinion regarding appropriate sampling designs and techniques. The disagreement between the two research groups derives mainly from different scientific viewpoints. One is based on a parochial view guided by the immediate needs of local site managers; the other takes a wider view of ecology, which uses a landscape-level approach to develop information with broader application. This Reply Comment clarifies several issues, refocuses attention on the scientific aspects of this discussion, and summarizes information needed to develop a wider perspective for future management of coastal impoundments, especially given anticipated changes in climate, sea level, and other global factors. We discuss the challenges of studying complex ecological systems with the goal of providing useful information to managers, who must often make difficult decisions.
\end{abstract}

KEY WORDS: Climate change - Sea level rise $\cdot$ Hurricanes $\cdot$ Landscape ecology $\cdot$ Wetland management $\cdot$ Mangrove $\cdot$ Marsh

Journal articles are simplifications of the complexities encountered in an investigation. Rey et al. (2009, this volume) point out some of the complexities that challenged the study by Middleton et al. (2008). Choices made during ecological studies are partly a reflection of the difficulties inherent in sampling at various landscape scales in complex systems. Rey et al. (2009) list 'errors of fact' and 'methodological problems', which are minor or unfounded, and which do not invalidate the findings of Middleton et al. (2008). Most issues raised by Rey et al. (2009) were in fact carefully considered during study design. Site information was based on historical photography, published literature, and extensive communications with site managers (including D. Carlson, co-author of the Comment, and his staff, who accompanied Middleton and co-workers to field sites). This information, which Rey et al. (2009) portray as being incorrectly attributed, was ascribed generally to managers during editing with no intent to misquote.

We wish to refocus attention on the chasm between current knowledge and the information required for sound management of the diverse and highly altered landscapes of the Indian River Lagoon (IRL), Florida, USA, and we assess the availability of relevant data to answer key questions about effects of mosquito impoundments as well as appropriate approaches to test their ecological impacts. We conclude with a list of information requirements in the context of global changes in sea level, climate, and hurricane activity. 


\section{MOSQUITO IMPOUNDMENTS IN FLORIDA, USA}

Mosquito impoundments in eastern Florida were created by encircling salt marsh or mangrove forest with earthen dikes (Provost 1959) (Fig. 1), which effectively block natural tidal fluctuation. By manipulating flood level and duration with pumps and other controls, mosquito populations can be reduced without use of pesticides. Hundreds of kilometers of ditches and dikes were created in the IRL, impounding $>16200$ ha of wetlands (Rey \& Kain 1990). Impoundments, however, had additional effects: alteration of
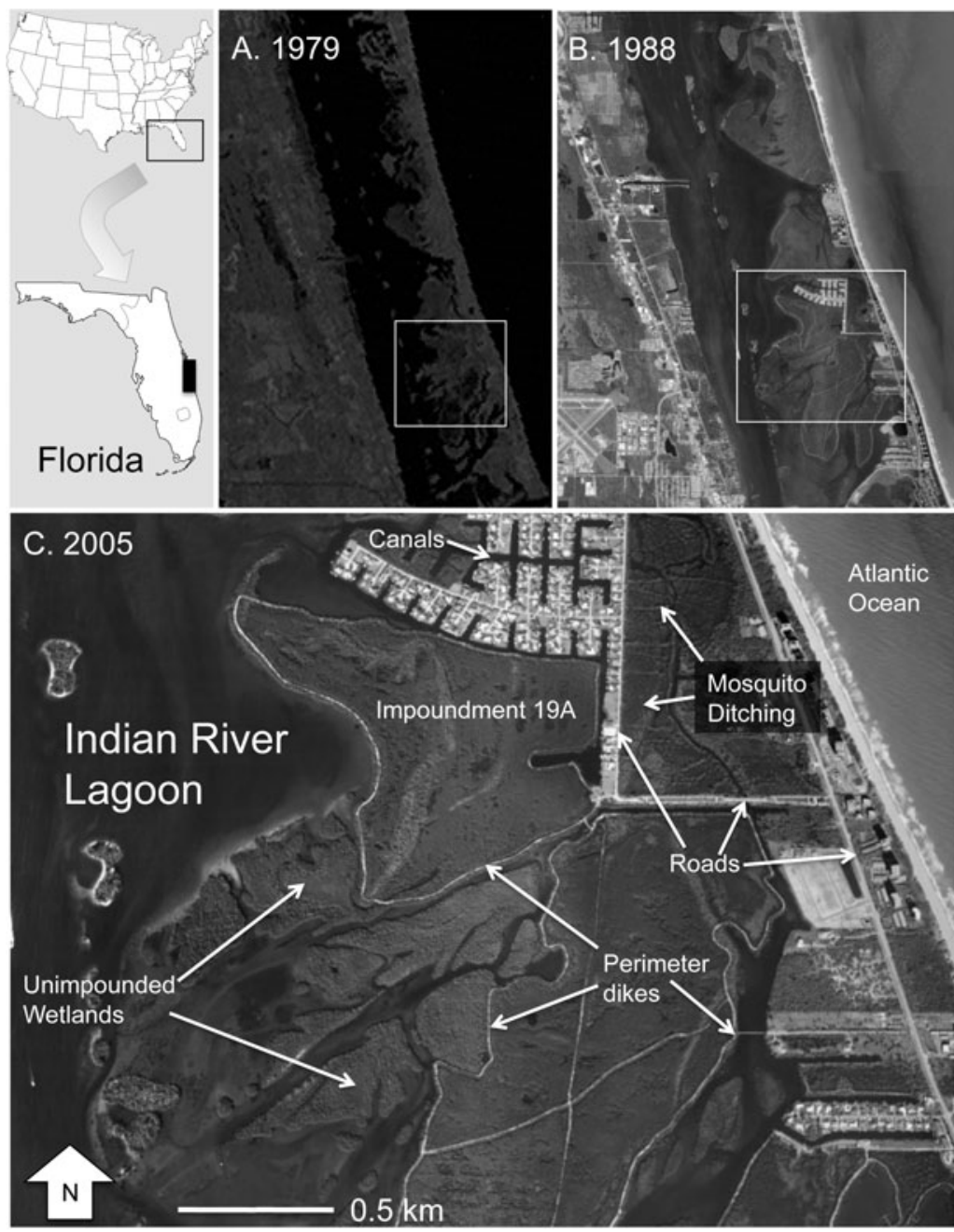

Fig. 1. Aerial images of a section of the Indian River Lagoon (IRL) $\left(27^{\circ} 30^{\prime} 54^{\prime \prime} \mathrm{N}, 80^{\circ} 18^{\prime} 28^{\prime \prime} \mathrm{W}\right)$ in (a) 1979 and (b) 1988, and close-up view in (c) 2005 of mosquito impoundments and adjacent non-diked (control) sites sampled by Middleton et al. (2008). Historical imagery of this section of the IRL shows increasing human activities from 1979 to 2005. Impoundment 19A (a RIM site constructed in 1963; Rey \& Kain 1990) was misidentified as a breached-RIM site in Middleton et al (2008); however, reanalysis shows that the comparisons remain the same as originally reported, with the exception that tree height was lower, and canopy openness was higher in breached-RIM than in control and RIM swamps. Image source: US Geological Survey plant species composition or elimination of vegetation Rey et al. 1990a), reduction in abundance and diverof fishes (Harrington \& Harrington 1961, 1982), poundment Management (RIM) was subsequently implemented, in which flooding occurred only during the mosquito reproductive season; at other times, water levels were allowed to fluctuate by opening culverts in the dikes. At some mosquito impoundments, permanent breaks in perimeter dikes (breached-RIM) allowed for more frequent water exchange with the adjacent lagoon. Middleton et al. (2008) conducted a landscape-level comparison of these 2 management types (RIM and breached-RIM) with nondiked ('natural') areas dominated by mangroves.

\section{METHODOLOGICAL CHALLENGES IN LANDSCAPE-LEVEL STUDIES}

Selection of appropriate statistical inference space. The sampling design used by Middleton et al. (2008) involved streamlined sampling of replicate sites in RIM, breached-RIM, and control categories (total of 20 sites), but with limited sub-sampling within sites. Rey et al. (2009) criticize this approach and suggest more intensive sampling at fewer sites. However, such an approach would have reduced the statistical inference space, because type of impoundment is the source of variation that requires replication and allows inference to other sites of the same type. The problem with unreplicated effects in ecological studies, sometimes referred to as 'pseudoreplication', has been discussed extensively (e.g. Heffner et al. 1996 and references therein). Pseudoreplication is a common methodological flaw that arises when the experimental unit is misidentified in relation to the main effect being tested. For example, some previous work on mosquito impoundments in the IRL did not replicate at the site (impoundment) level (Table 1). Instead, multiple samples were collected within sites. Consequently, differences between 2 sites, for example, which may be due to unknown factors other than impoundment type, can be confounded. 
Table 1. Summary of research on mosquito impoundments in the Indian River Lagoon (IRL), Florida, USA; number of impounded (diked) or 'natural' sites and number of within-site samples. n: number of samples; ng: not given

\begin{tabular}{|c|c|c|c|c|c|}
\hline Site & Diked & Natural & $\mathrm{n}$ & Subject & Source \\
\hline IRC 12 & 0 & 1 & ca. $12^{\mathrm{a}}$ & Fish & Harrington \& Harrington (1961) \\
\hline IRC 12, IRC 23 & 2 & 0 & $\mathrm{ng}^{\mathrm{a}}$ & Fish & Gilmore et al. (1982) \\
\hline IRC 12 & 1 & 0 & ca. $12^{\mathrm{a}}$ & Fish & Harrington \& Harrington (1982) \\
\hline $\begin{array}{l}\text { N John Knights 2, PineIs 6, Oslo, Morgans 29, } \\
\text { Vickers 30, Golf 22, VRoyale }\end{array}$ & 7 & 0 & 24 to $96^{\mathrm{a}}$ & Water quality & Carlson (1983) \\
\hline MCD 2, MCD 10A; Control: near MCD 2 & 2 & 1 & 3 to $60^{\mathrm{a}}$ & Vegetation, peat & Lahmann (1988) \\
\hline IRC 12, SLC 24 & 2 & 0 & $60^{\mathrm{a}}$ & Vegetation & Rey et al. (1990a) \\
\hline T10H, Boggy Pond & 2 & 0 & 1 to $6^{\text {a }}$ & Fish, water quality & Rey et al. (1990b) \\
\hline IRC 12, North Marsh; Control: Oslo & 2 & 1 & 20 & Vegetation & Rey et al. (1990c) \\
\hline IRC 14, IRC 16; Control: IRL & 2 & 1 & 1 to $5^{\mathrm{a}}$ & Fish, water quality & Rey at al. (1990d) \\
\hline IRC 12, SLC 23; Control: IRL & 2 & 1 & $\mathrm{ng}^{\mathrm{a}}$ & Zooplankton & Rey et al. (1991) \\
\hline IRC 12, Blue Hole; Control: unnamed tidal creek & 2 & 1 & $10^{\mathrm{a}}$ & Water sulfide & Rey et al. (1992) \\
\hline IRC 12, SLC 23; Control: Oslo & 2 & 1 & 6 to $12^{\mathrm{a}}$ & Soil characterization & Rey and Kain (1993) \\
\hline IRC 12 & 1 & 0 & 3 & Mangrove seedlings & Rey (1994) \\
\hline IMP 19A, IMP 19B, IMP 23, IMP 24 & 4 & 0 & $4^{\mathrm{a}}$ & Fish, decapods & Lin \& Beal (1995) \\
\hline Brevard Co before and after impoundment & 1 & 1 & $3^{\mathrm{a}}$ & Fish & Taylor et al. (1998) \\
\hline Banana Creek & 1 & 0 & $4^{\mathrm{a}}$ & Fish & Stevens et al. (2006) \\
\hline $\begin{array}{l}\text { Hole Is, Moorings, Pine Is, Schlitts, Knights, Vista, } \\
\text { IMP 1, 3, 14A/B, 24; 19A/B, Control: Barker Is., } \\
\text { Roosevelt Is., Preacher Is., Oslo, ELC, HookPt, } \\
\text { near 19A }\end{array}$ & 13 & 7 & 2 & Vegetation, soil, water & Middleton et al. (2008) \\
\hline aSampling was conducted more than once & & & & & \\
\hline
\end{tabular}

Middleton et al. (2008) avoided pseudoreplication by identifying multiple sites within each of 3 categories: 10 RIM, 3 breached-RIM and 7 'control' sites, which were all spatially distinct and spread across $>100 \mathrm{~km}$ of coastline in the IRL (see Fig. 1 in Middleton et al. 2008). Even this effort was not sufficiently broad to allow inference to the entire IRL, a vast estuary spanning subtropical and temperate latitudes.

Another point supporting the design of Middleton et al. (2008) is that multiple variables could be assessed simultaneously in replicated impoundment types. The pattern of differences in vegetation, litter, and soil factors were consistent with the hydrological characteristics of RIM, breached-RIM, and control areas (Fig. 2 in Middleton et al. 2008). Multivariate analysis also showed that the site types separated into 3 distinct groups based on the combined variables (Fig. 4 in Middleton et al. 2008). A comparison with natural mangroves across a broader geographic area further confirmed the differences between impounded and control sites (Table 2 and Fig. 3 in Middleton et al. 2008).

Selection of control sites and representative sampling. Comparison of altered sites with a reference state or 'control' is important to gauge the effects of management practices on natural systems. Middleton et al. (2008) used the term 'natural' or 'control' to distinguish unimpounded from impounded sites, although there are few truly natural mangrove wetlands remaining in the IRL. Non-diked control sites were selected as close to impounded sites as possible, where visual assessments indicated little direct human influence (Fig. 1).

Rey et al. (2009) suggest that the only appropriate choice of controls is high marsh habitat, which characterized managed sites prior to impoundment. We disagree. A control site must be selected to represent the original, current, or potential future characteristics, depending on the research question. The impoundments in the portion of the IRL studied by Middleton et al. (2008) were dominated by mangrove vegetation, in contrast to impoundments farther north with mostly saline marsh (e.g. at Merritt Island). Field observations and historical photography also indicated that the current vegetation in the studied impoundments was similar to that in adjacent mangrove areas with which they were once contiguous (Fig. 1). Consequently, Middleton et al. (2008) compared impounded sites (with mangrove vegetation and extended hydroperiod) with nondiked mangrove sites. If high marsh sites had been used as controls, differences may have been much greater and possibly not very informative, given expected shifts in vegetation due to climate change and sea level rise.

Sampling the entire population (of potential samples) is seldom possible, so some subset must be selected for measurement and then subjected to statistical analysis. Ideally, the samples collected are representative of the entire population of samples. From a practical standpoint, however, the number of samples taken must be weighed against statistical, logistical, financial, and time constraints. Sampling by Middleton 
et al. (2008) was maximized at site level and thus represented a measure of true variability within and among management types. Intensive sampling of a single replicate marsh of a given management type (or control) does not allow for any measure of among-site variability. Because random samples tend to be, on average, representative (and are also unbiased and independent) (Underwood 1997), Middleton et al. (2008) selected 2 plots in a potential area $\left(50 \mathrm{~m}^{2}\right)$ designated by a $50 \mathrm{~m} \times 1 \mathrm{~m}$ transect belt. Transects were consistently located parallel to and equidistant from the shoreline; this minimized differences in elevation and tidal influence within and across sites. Except for propagule density, the 2 random plots were not significantly different (Table 1 in Middleton et al. 2008).

Selection of sampling techniques. Rey et al. (2009) questioned the methods used by Middleton et al. (2008) to assess species dominance and litter cover. Density of each mangrove species was estimated by counting the individual trees intercepted by a transect line. Plant ecologists have traditionally used 'distance' or 'plotless' sampling techniques to obtain rapid estimates of density in vegetation types where individual plants are well defined and distinctly spaced, such as in forests (Cottam \& Curtis 1956). Plotless sampling is much more efficient than quadrat sampling, especially for rapid sampling in widely-spaced sites and mangrove forests, where searching for and counting individuals in a large area is extremely time consuming and logistically difficult. Not surprisingly, plotless methods (e.g. line-intercept, point-centered quarter, nearest neighbor) are often recommended for use in mangrove forests (e.g. Cintron \& Novelli 1984). The relative dominance of species was also visually assessed and found to agree with transect data.

Percent litter cover in random plots was visually estimated as the proportion of ground covered by leaf litter. Categories were used $(0,1,5,25,50,75,100 \%)$ as recommended by traditional phytosociologists (sensu Braun-Blanquet 1965), providing a more consistent and accurate measure, for comparative purposes. In any case, the main difference would not have been improved with a more 'quantitative' approach; litter cover was 67 to $75 \%$ at breached-RIM and RIM sites compared to $<1 \%$ at control sites.

Exotic invasion. Middleton et al. (2008) found that Brazilian pepper Schinus terebinthifolius occurred infrequently within mosquito impoundments (observed at only 1 site). This species is found more frequently on perimeter dikes where the soils are disturbed and elevated (Carlson 1983, Schmalzer 1995). To our knowledge, there has not been an extensive survey of $S$. terebinthifolius occurrence in association with impoundment dikes, but such information might provide additional insight into how impoundments influence invasion by exotic vegetation.

\section{DATA REQUIREMENTS FOR MANAGEMENT}

Middleton et al. (2008) found that RIM, breachedRIM, and control sites differed in a number of characteristics, a finding that agreed with previous work showing significant effects of mosquito impoundments on soils, vegetation, fishes, and other features. We found 17 studies on impoundments in which original data were collected at 1 or more sites in the IRL (Table 1); 13 of these involved only 1 or 2 replicates at the site level. Only 2 studies were carried out at 7 or more sites (Carlson 1983, Middleton et al. 2008). Fewer than half of the studies included 'natural' sites for comparison. The principal subjects were fishes (8), physicochemical (7), and vegetation (5). Most studies examined only 1 variable. Half of the studies (9) were conducted at one impounded site: IRC 12 in St. Lucie County. Although that site appears to have been studied for many years, the data on vegetation, animals, soils, and pore water chemistry should not be generalized to all impoundments in the IRL (see 'Methodological challenges in landscape-level studies').

Middleton et al. (2008) was the first study since 1983 to publish landscape-level information on mangrovedominated impoundments in the IRL. It is a small first step in acquiring key information needed to manage these complex wetlands in the future. To our knowledge, there has been no comprehensive assessment of tidal restriction in IRL impoundments under different management regimes or how biophysical processes may be affected.

\section{GLOBAL CHANGE AND COASTAL WETLANDS}

Landscape-level information must address questions related to climate and other drivers of global change (e.g. Middleton \& McKee 2004). Data collected at relevant spatial and temporal scales are particularly critical, as management of wetlands in the IRL must consider anticipated changes, e.g. in sea level. Here, we focus on 3 major concerns: (1) vertical adjustment of soil elevations to counterbalance rising sea level and diminishing sediment supplies, (2) migration of wetland species as sea level and climate change, and (3) impacts of storms and hurricanes.

Sea level rise. Coastal wetlands exist in a narrow vertical plane where minor changes in tidal amplitude have profound effects on the distribution of salt marsh vegetation (McKee \& Patrick 1988). Salt marshes and mangroves build up through accretion of mineral and organic matter (Cahoon et al. 2006, McKee et al. 2007). Disruption of sediment delivery or organic matter accumulation result in the dominance of subsidence and eustatic sea level rise, and coastal wetlands become 
submerged (e.g. Cahoon et al. 2003). Accelerated sealevel rise (Solomon et al. 2007) will increase the rate of submergence of coastal wetlands worldwide. The construction of dikes, canals, roads, and other structures (Fig. 1) can alter or block movement of water and sediment, but limited information is available on elevation dynamics in Florida's mosquito impoundments (Lahmann 1988). Cahoon et al. (2004) report differences in elevation trajectories ( 2 yr trend) among impounded, restored, and 'native' marshes in the northern IRL, depending upon substrate type (vegetated, mudflat), antecedent topography, and date and degree of hydrologic reconnection. Some impounded sites without marsh vegetation showed subsidence $>20 \mathrm{~mm}$, whereas vegetated areas maintained soil elevations relative to sea level (Cahoon et al. 2004).

Barriers to migration. The distribution of wetland communities is expected to shift as changes in climate and sea level occur. The IRL is unique in that it represents the convergence of two major vegetation types (mangrove and salt marsh) (Virnstein 1990). Mangroves are expected to migrate northward as the climate warms, and marsh and mangrove species may redistribute locally along an elevation gradient from shore to upland. However, barriers to species migration will modify local and geographic movements. How the extensive network of dikes in the IRL will influence migration is unknown, but such information is needed to understand how the ecosystem will respond. Genetic diversity of local populations may also play a role in climate change responses (Proffitt et al. 2003), but lack of data for the IRL will make predictions difficult.

Storms and hurricanes. Storm and hurricane effects on wetland habitat stability can be significant, with scouring and eroding forces removing sediment and organic material from soil surfaces (Guntenspergen et al. 1995). Storm surge events may also result in significant delivery of sediment to wetlands (Turner et al. 2006), raising elevations and countering sea level rise and subsidence (McKee \& Cherry 2009). The barriers to water movement created by dikes and impoundments are likely to influence the episodic removal or delivery of sediments and overall resilience of coastal wetlands, but specific information regarding sediment and organic matter dynamics in these systems is limited (Blum 2004, Cahoon et al. 2004).

Management information needs. Plans for future stewardship of coastal habitats will require data that more effectively reveal impacts of direct human alterations in concert with the broader forces of global change. Management and restoration of coastal wetlands must also consider what the appropriate target should be, especially if conditions no longer support the historic flora and fauna of a region.
Given the impending changes predicted for coastal zones, managers must work closely with scientists to set priorities regarding key information needs for impounded wetlands, including: (1) rates of accretion, subsidence, and elevation change, (2) rates and patterns of sediment delivery, (3) location and height of barriers to species migration, (4) rates of organic matter accumulation (and loss due to oxidation) and how impoundments promote or retard production and decomposition, (5) genetic diversity of key species and their response to anticipated changes in environmental conditions, (6) better understanding of ecosystem resilience and how to enhance it, and (7) locations for potential refugia to conserve local biodiversity. Such information should span the entire latitudinal range of the IRL to include saline marsh in the north and mangroves in the south.

\section{CONCLUDING THOUGHTS}

The complex and variable nature of large estuarine systems such as the IRL poses major challenges to both ecologists and managers (Virnstein 1990). At the same time, mosquito impoundments have substantially altered the natural landscape of the IRL. Their management has undergone modifications as studies have brought new insights, but a landscape-level approach is required to generalize beyond a few locations. Coastal management programs also require information about how global changes in sea level, climate, and other factors may interact with management practices. Such large-scale and complex issues are not easily addressed using small-scale methods. Given predictions of future conditions affecting coastal zones worldwide (Solomon et al. 2007), managers of sensitive habitats need information from multiple unbiased and diverse sources. Middleton et al. (2008) took a broader view by examining multiple variables that reflect ecological integrity over a large geographic area. The goal of that study was to provide information upon which managers might base decisions and to suggest directions for future research.

Acknowledgements. We thank R. Dale for statistical advice and J. Grace and E. Ramsey for comments on earlier versions of the Reply Comment. J. Rey and J. David provided information used to prepare Fig. 1.

\section{LITERATURE CITED}

Blum LK (2004) Organic matter dynamics. In: Brockmeyer RE Jr (ed) Optimizing IRL wetland habitat restoration and management: the IRL wetlands initiative, draft final report to the U.S. Environmental Protection Agency, p 92-101

Braun-Blanquet J (1965) Plant sociology: the study of plant communities. Hafner, London 
Cahoon DR, Hensel P, Rybczyk J, McKee KL, Proffitt CE, Perez BC (2003) Mass tree mortality leads to mangrove peat collapse at Bay Islands, Honduras after Hurricane Mitch. J Ecol 91:1093-1105

Cahoon DR, Lowers RH, Reyier EA, Stewart JB, Hensel PF (2004) Recent accretion rates. In: Brockmeyer RE Jr (project manager) Optimizing IRL wetland habitat restoration and management: the IRL wetlands initiative, draft final report to the U.S. Environmental Protection Agency, p 81-91

Cahoon DR, Hensel PF, Spencer T, Reed DJ, McKee KL, Saintilan N (2006) Coastal wetland vulnerability to relative sea-level rise: wetland elevation trends and process controls. In: Verhoeven JTA, Beltman B, Bobbink R, Whigham DF (eds) Wetlands and natural resource management. Springer-Verlag, Berlin, p 271-292

Carlson DB (1983) The use of salt-marsh mosquito control impoundments as wastewater retention areas. Mosq News 43:1-6

Cintron G, Novelli YS (1984) Methods for studying mangrove structure. In: Snedaker SC, Snedaker JG (eds) The mangrove ecosystem: research methods. UNESCO, Paris, p 91-113

$>$ Cottam G, Curtis JT (1956) The use of distance measures in phytosociological sampling. Ecology 37:451-460

Gilmore RG, Cooke DW, Donohoe CJ (1982) A comparison of the fish populations and habitat in open and closed salt marsh impoundments in east-central Florida. Northeast Gulf Sci 5:25-37

Guntenspergen GR, Cahoon DR, Grace J, Steyer GD, Fournet S, Townson MA, Foote AL (1995) Disturbance and recovery of the Louisiana coastal marsh landscape from the impacts of Hurricane Andrew. J Coast Res 21:324-339

Harrington RW, Harrington ES (1961) Food selection among fishes invading a high subtropical salt marsh: from onset of flooding through the progress of a mosquito brood. Ecology 42:646-666

Harrington RW Jr, Harrington ES (1982) Effects on fishes and their forage organisms of impounding a Florida salt marsh to prevent breeding by salt marsh mosquitoes. Bull Mar Sci 32:523-531

Heffner RA, Butler MJ, Reilly CK (1996) Pseudoreplication revisited. Ecology 77:2558-2562

Lahmann EJ (1988) Effects of different hydrological regimes on the productivity of Rhizophora mangle L.: a case study of mosquito control impoundments at Hutchinson Island, Saint Lucie County, Florida. PhD thesis, University of Miami, Coral Gables, FL

Lin J, Beal JL (1995) Effects of mangrove marsh management on fish and decapod communities. Bull Mar Sci 57: 193-201

McKee, KL, Cherry JA (2009) Hurricane Katrina sediment slowed elevation loss in subsiding brackish marshes of the Mississippi River delta. Wetlands 29:2-15

McKee KL, Patrick WH Jr (1988) The relationship of smooth cordgrass (Spartina alterniflora) to tidal datums: a review. Estuaries 11:143-151

- McKee KL, Cahoon DR, Feller IC (2007) Caribbean mangroves adjust to rising sea level through biotic controls on change in soil elevation. Glob Ecol Biogeogr 16:545-556

Middleton BA, McKee KL (2004) Use of a latitudinal gradient in bald cypress (Taxodium distichum) litter production to examine physiological controls on biotic boundaries and potential responses to environmental change. Glob Ecol Biogeogr 13:247-258

Editorial responsibility: Matthias Seaman,

Oldendorf/Luhe, Germany
Middleton B, Devlin D, Proffitt E, McKee K, Getini KF (2008) Characteristics of mangrove swamps managed for mosquito control in eastern Florida, USA. Mar Ecol Prog Ser 371:117-129

Proffitt CE, Travis S, Edwards K (2003) Genotype and elevation influence Spartina alterniflora colonization and growth in a created marsh. Ecol Appl 13:180-192

Provost MW (1959) Impounding salt marshes for mosquito control and its effects on bird life. Fla Nat 32:163-170

Rey JR (1994) Effects of neighbors on growth and mortality of mangrove seedlings in Florida, USA. Wetlands 14: 308-315

Rey JR, Kain T (1990) A guide to the salt marsh impoundments of Florida. University of Florida, Florida Medical Entomology Laboratory, Vero Beach, FL

Rey JR, Kain T (1993) Chemical characteristics of soils in natural and impounded wetlands along the Indian River Lagoon, Florida, USA. J Fla Mosq Control Assoc 64: 53-62

Rey JR, Crossman RA, Kain TR (1990a) Vegetation dynamics in impounded marshes along the Indian River Lagoon, Florida, USA. Environ Manage 14:397-409

Rey JR, Peterson M, Kain T, Vose FE, Crossman R (1990b) Fish populations and physical conditions in ditched and impounded marshes in east-central Florida. Northeast Gulf Sci 11:163-170

Rey JR, Shaffer J, Crossman R, Tremain D (1990c) Aboveground primary production in impounded, ditched, and natural Batis-Salicornia marshes along the Indian River Lagoon, Florida, U.S.A. Wetlands 10:151-171

Rey JR, Shaffer J, Tremain D (1990d) Effects of re-establishing tidal connections in two impounded subtropical marshes on fishes and physical conditions. Wetlands 10: $27-45$

Rey JR, Crossman R, Peterson M, Shaffer J, Vose F (1991) Zooplankton of impounded marshes and shallow areas of a subtropical lagoon. Fla Sci 54:191-203

Rey JR, Shaffer J, Kain T, Stahl R, Crossman R (1992) Sulfide variation in the pore and surface waters of artificial saltmarsh ditches and a natural tidal creek. Estuaries 15: 257-269

Rey JR, O'Connell SM, Carlson DB, Brockmeyer RE (2009) Comment: Characteristics of mangrove swamps managed for mosquito control in eastern Florida, USA: a re-examination. Mar Ecol Prog Ser 389:295-300

Schmalzer PA (1995) Biodiversity of saline and brackish marshes of the Indian River Lagoon-historic and current patterns. Bull Mar Sci 57:37-48

Solomon S, Qin D, Manning M, Chen Z and others (eds) (2007) Climate change 2007: the physical science basis. Cambridge University Press, Cambridge

Stevens PW, Montague CL, Sulak KJ (2006) Fate of fish production in a seasonally flooded saltmarsh. Mar Ecol Prog Ser 327:267-277

Taylor DS, Poulakis GR, Kupschus SR, Faunce CH (1998) Estuarine reconnection of an impounded mangrove salt marsh in the Indian River Lagoon, Florida: short-term changes in fish fauna. Mangroves Salt Marshes 2:29-36

Turner RE, Baustian JJ, Swenson EM, Spicer JS (2006) Wetland sedimentation from Hurricanes Katrina and Rita. Science 314:449-452

Underwood AJ (1997) Experiments in ecology. Cambridge University Press, Cambridge

Virnstein RW (1990) The large spatial and temporal biological variability of Indian River Lagoon. Fla Sci 53:249-256

Submitted: July 20, 2009; Accepted: August 4, 2009

Proofs received from author(s): August 7, 2009 